\title{
Lime mud from cellulose industry as raw material in cement mortars
}

\author{
R.C.E. Modolo ${ }^{a} \bowtie$, L. Senff ${ }^{b}$, J.A. Labrincha ${ }^{a}$, V.M. Ferreira ${ }^{a}$, L.A.C, Tarelho ${ }^{c}$ \\ a. University of Aveiro/CICECO (Aveiro, Portugal) \\ b. Center of Mobility Engineering (CEM), Federal University of Santa Catarina (UFSC) (Joinville, SC, Brasil) \\ c. University of Aveiro/CESAM (Aveiro, Portugal) \\ $\triangle$ regina.modolo@ua.pt
}

\author{
Received 6 January 2014 \\ Accepted 9 May 2014 \\ Available on line 14 October 2014
}

\begin{abstract}
This study reports the use of lime mud (LM) in cement-based-mortars. Lime mud is a waste generated in the production of cellulose by the kraft mill process. It is mainly composed of $\mathrm{CaCO}_{3}$, a small amount of magnesium carbonate and other trace minerals. Mortars were prepared by adding different amounts of $\operatorname{LM}(10,20$ and $30 \%$ by weight of cement) in dry weight. The mortar compositions were evaluated through rheology and flow table measurements, assuring that all the samples exhibited adequate conditions for testing in both equipments. The hardened state properties were also evaluated through mechanical strengths at 7, 28 and 90 days of curing. Following a waste management solution perspective, this work intend to provide a general evaluation of LM application in cement based mortars, looking at both fresh and hardened properties in order to guarantee that the final application requirements are not hindered.
\end{abstract}

KEYWORDS: Mortars; Lime mud; Characterization; Valorization

Citation / Citar como: Modolo, R.C.E.; Senff, L.; Labrincha, J.A.; Ferreira, V.M.; Tarelho, L.A.C. (2014) Lime mud from cellulose industry as raw material in cement mortars. Mater. Construcc. 64 [316], e033 http://dx.doi. org/10.3989/mc.2014.00214.

RESUMEN: Lodo de carbonato de la industria de celulosa como materia prima en las morteros de cemento. Este estudio revela el uso de lodo de carbonato (LM) en morteros de cemento. El LM es un residuo compuesto principalmente por $\mathrm{CaCO}_{3}$ generado en la producción de pasta de papel por el método Kraft. Los morteros se prepararon a partir de la adición de diferentes niveles de LM (10, 20 y 30\% en peso de cemento) en peso seco. Las composiciones de los morteros fueron caracterizadas através de mediciones de reología de mesa y de flujo, asegurando que las muestras exhibían condiciones adecuadas para su caracterización en ambos equipamientos. Las propiedades en estado endurecido también se evaluaron através de resistencias mecánicas a los 7, 28 y 90 días de cura. Con objeto de gestión de residuos, este trabajo tiene la intención de proporcionar una visión general de la aplicación de LM en los morteros, haciendo hincapié en las propiedades con el fin de garantizar que los requisitos para su aplicación final no se vean obstaculizados.

PALABRAS CLAVE: Morteros; Lodo de carbonato; Caracterización; Valorización

Copyright: (C) 2014 CSIC. This is an open-access article distributed under the terms of the Creative Commons Attribution-Non Commercial (by-nc) Spain 3.0 License.

\section{INTRODUCTION}

The negative influence of wastes on the construction materials properties require further research in order to optimize the characteristics of them. In recent years, the environmental damage and the wastes generated from industrial activity, increased significantly worldwide and one of the most common solid waste disposal means is in controlled landfills. Thus, the raw natural materials have become scarce and the adverse impacts on the environment are visible (1-3). Best available techniques for reducing 
waste is to minimize the generation of solid waste and/or use these by products as alternative rawmaterials, wherever practicable.

Pulp and papers mills generates thousands tons of solid waste (organic and inorganic) every year that go for landfill disposal (mainly inorganic types). The amount and the composition of these wastes depend necessarily on the process techniques applied and the raw materials used to obtain the pulp and/or the paper quality desired. In general, the solid waste composition from pulp and paper mills is known and constant, as a result of the current, highly controlled production process which permits the use and valorisation of the wastes in safe and environmental way (4). Some applications of theses wastes have been frequently researched including aggregates for bituminous mixtures $(5)$, cement $(6,7)$, brick $(8)$ and fiber-cement (9). From pulp mills, inorganic sludges are separated from the chemical recovery cycle and normally landfilled after dewatering. Lime mud is an industrial pulp and paper kraft mill solid waste of the chemical recovery unit (Figure 1). It has the code 030309 in the European List of wastes (2004) (10). It is mainly composed by calcium carbonate, small amount of magnesium carbonate and other trace minerals $(11,12)$. Normally, the major part of this sludge is used as raw-material in the limestone make up process. Although this waste is partially used as raw-material in the own pulp and paper process, in this specific case, due to limitations of the lime kiln, the limestone make-up does not drain all lime mud generated by the production process. Then, the lime mud surplus has been landfilled (approximately 500 tons/month in wet base). Essentially, the production of industrial pre-mixed mortars exceeds several million tons each year, consuming a huge amount of natural but pre-treated raw materials (e.g. siliceous sand) as aggregate as well as cement. This activity could be looked as a target for the use of lime mud, as currently happens with the ashes generated from the coal and biomass combustion in concrete $(13,14)$. Several studies related with the use of wastes as filler, aggregates or cement replacement material in mortars or concrete have been researched. Some of them indicate that may be the wastes could be classified as a pozzolanic material (i.e. cane bagasse ash), but some points that their activity depends significantly on its particle size and fineness (14-19). Specifically, some uses for lime mud, such as in bricks, cement and pavements could be good alternatives to drain huge amounts of this solid waste. Eroğlu (2006) (20) tested lime mud also as soil stabilization of forest roads. The results obtained showed that roads deformation could be stabilized and maintained by using lime mud. In another work, lime mud was tested as additive in composite cement and the results confirmed it as a potential waste for this application (21). The use of limestone fillers in concrete and mortars has becoming more and more common in recent years, pushed by economic and ecological drivers. Even the cement production is now dominated by type II formulations, where the clinker is partially replaced by limestone fillers (up to $35 \mathrm{wt} . \%$ ). In most cases limestone fillers simply acts as a component in the cement/mortar (22-24). However, European Standards relating to aggregates for mortars (EN 13139: 2003) (25) allows up to $22 \%$ in mass as an aggregate component.

Following the waste management perspective of finding an efficient alternative of lime mud valorisation, this work intend to show, through bench scale developed work, a solution for this waste incorporation in cement-based materials providing not only a general approach of lime mud characteristics, but also present results about the final product properties (mortars) in the fresh and hardened state.

\section{EXPERIMENTAL PROCEDURE}

Lime mud (LM) sample was used as collected, from a rotary filter chamber located in a pulp paper plant in Aveiro, Portugal. Ordinary Portland cement (OPC) type II $-32.5 \mathrm{~N}$, produced with $65-79 \%$ of clinker, $21-35 \%$ of lime and $0-5 \%$ other components including calcium sulphate as setting regulator, was used in the present study to prepare pastes and mortars. OPC has an average particle size of $14 \mu \mathrm{m}$.

Avoiding energy costs in the future the lime mud was tested without dewatering. The moisture content $(34 \% \mathrm{wt}$ ) was kept as collected and used in the mortars production. The water final ratio was calculated adding up the waste water content plus additional fresh water. Siliceous sand was sieved through a 1.18 $\mathrm{mm}$ before use in the mixture as aggregate. Its average size is $0.830 \mathrm{~mm}$. The particle size distribution of LM was performed using a Coulter LS particle size analyzer (LS230FM). The real density of LM particles was determined with picnometer method (ISO/ TS 17892-3/2004) (26). The specific surface area was measured by nitrogen adsorption method according to Brunauer, Emmett and Teller (BET). Thermal gravimetric and differential thermal analyses (TG/ DTA) of the LM were performed up to $1000{ }^{\circ} \mathrm{C}$ with a heating rate of $10^{\circ} \mathrm{C} / \mathrm{min}$, in a simultaneous TG/DTA (STA 409 EP). The chemical composition of the LM and CEM II $32.5 \mathrm{~N}$ were evaluated using $\mathrm{X}$-ray fluorescence spectroscopy using a Panalytical Axios spectrometer. The microstructure of the LM was studied using a scanning electron microscope (SEM - Hitachi SU-70). The chloride content was determined in the solid waste (LM) and in the mortars by the Argentometric method (CHLORIDE, 4500- $\mathrm{Cl}^{-}$; Standard Methods Committee, 1997). The sulfate content was determined in LM by Gravimetric method (SULFATE, 4500-SO ${ }_{4}^{-2}$; ignition of residue, Standard Methods Committee, 1997). Cement pastes $(\mathrm{w} / \mathrm{b}=50 \mathrm{wt} . \%)$ and cement mortars $(\mathrm{w} / \mathrm{b} \sim 62$ wt.\%) were prepared using different amounts of 


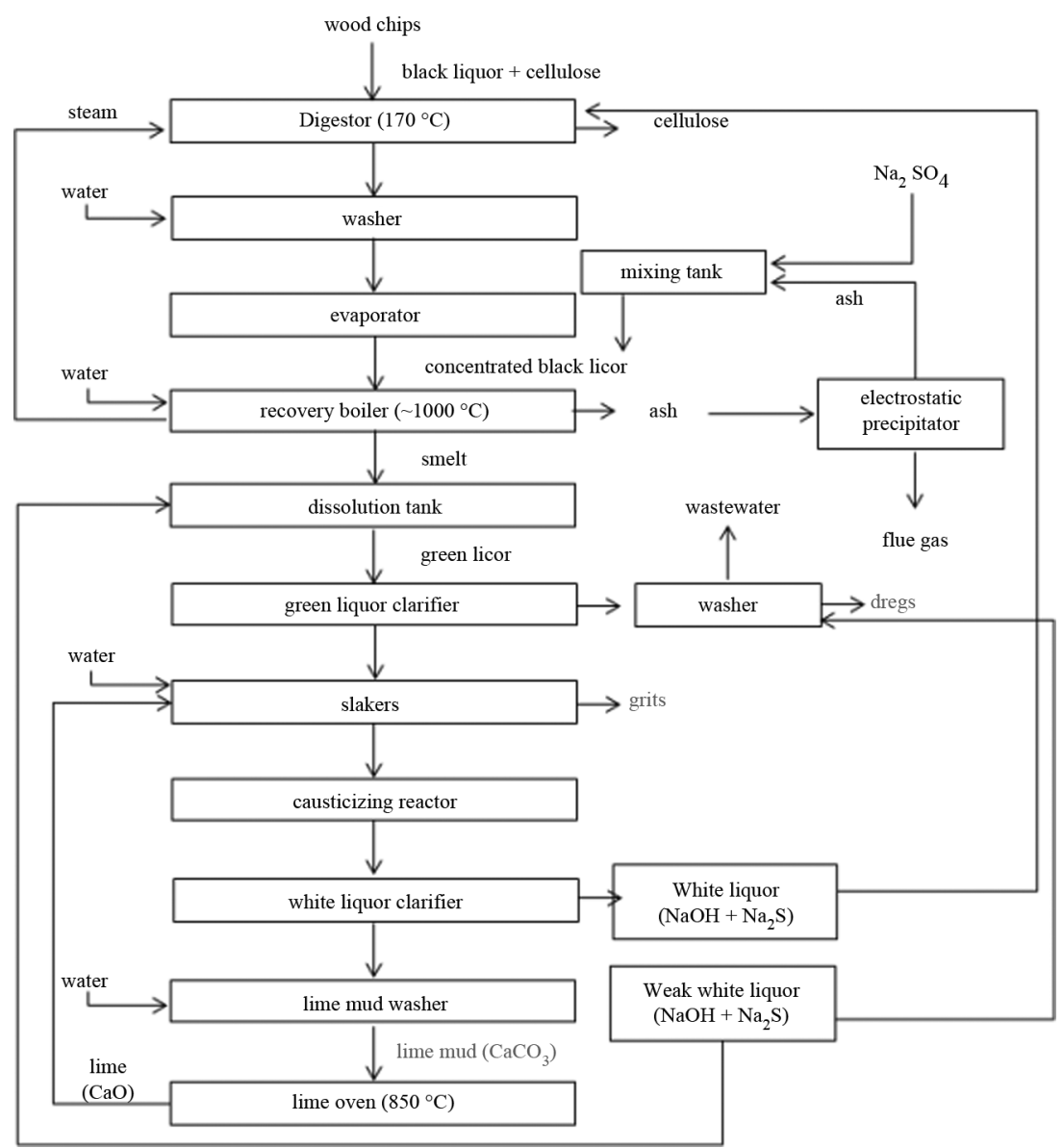

FIGURE 1. Kraft process flowsheet example; waste under study generated in the caustification line is written in gray color.

LM (10, 20 and $30 \%$ by weight of cement) in dry weight. The amount of water used in the mixtures was defined regarding the dosage of LM, in order to obtain an adequate workability condition to test in the rheometer and flow table. The workability of mortars was determined through rheology and flow table measurements, assuring that all samples exhibited an adequate condition in both equipment. In this way, it was possible to obtain a more complete characterization in the fresh state. The complete cement-mortars formulations are shown in Table 1.
The procedures used to prepare the formulations included: (i) placing lime mud into the water; (ii) mixing for $1 \mathrm{~min}$ at a low rotation speed of $60 \mathrm{rpm}$; (iii) stopping for $1 \mathrm{~min}$; (iv) mixing again for $1 \mathrm{~min}$ at a higher rotation speed $(120 \mathrm{rpm})$. A rheometer (Viskomat PC model, Schleibinger) was used to measure the rheological behaviour of fresh mortars, using a maximum speed rotation $(100 \mathrm{rpm})$ and $60 \mathrm{~min}$ of total test time. The rheological parameters (yield stress and plastic viscosity), was defined by using the Bingham model (27-30). The workability

TABLE 1. Cement-mortars formulations

\begin{tabular}{lcccccc}
\hline & Cement & Sand & $\begin{array}{c}\text { Lime-mud } \\
\text { (dry base) }\end{array}$ & & $\begin{array}{c}\text { Super } \\
\text { Plastisizer }\end{array}$ & Water \\
\cline { 2 - 3 } \cline { 6 - 7 } Formulations & \multicolumn{3}{c}{ \% (total mass) } & & & \% (total solid mass) \\
\hline Control & 25.0 & 75.0 & 0.0 & & 0.0018 & 15.5 \\
LM10\% & 24.4 & 73.2 & 2.4 & & 0.0017 & 15.1 \\
LM20\% & 23.8 & 71.4 & 4.8 & & 0.0017 & 14.8 \\
LM30\% & 23.3 & 69.8 & 7.0 & & 0.0017 & 14.4 \\
\hline
\end{tabular}

*LM was used as collected on formulations (with $\sim 34 \%$ of moisture content). 
of mortars was also measured through the spread diameter on flow table, according to EN 1015-3:1999 (31). The setting time of samples was determined by the Vicat needle penetration method following EN 196-3:2005 (32), while the kinetic of hydration was determinate in a quasi-adiabatic calorimeter.

For the mechanical test (flexural and compressive tests, EN 1015-11:1999) (33), mortars specimens with $40 \times 40 \times 160 \mathrm{~mm}$ were produced and tested after 7,28 and 90 days cured in standard conditions (temperature $=22{ }^{\circ} \mathrm{C}$ and relative humidity $=65 \%$ ) (EN 1015-2:1998) (34). Apparent density and water absorption were also determined by the immersion technique according to EN 1015-10:1999 (35). Capillary was measured in mortars specimens according to EN 1015-18:2002 (36).

The crystalline phases of LM and mortars were detected by X-ray diffraction - XRD (equipment RIGAKU-Geiger flex diffractometer).

\section{RESULTS AND DISCUSSION}

\subsection{Characterisation of lime mud}

The particle size distribution of LM was typically below $26 \mu \mathrm{m}$ being the size average around $10 \mu \mathrm{m}$ (Figure 2). The real density and the BET surface area of LM and OPC are presented in Table 2. LM real density was slightly lighter than OPC. LM presented a surface area of $5.17 \mathrm{~m}^{2} / \mathrm{g}$ and its microstructure is shown in Figure 3. Microstructure of Lime mud. The chemical analysis of LM is shown in Table 2. LM contained a chloride content of $0.08 \mathrm{mg} / \mathrm{kg}$ and sulphate content $0.05 \mathrm{mg} / \mathrm{kg}$. The presence of chlorides in cementitious materials can accelerate the setting time and together sulphates can also reduce durability by deterioration of microstructure (15). LM is basically constituted by calcium carbonate $\left(\mathrm{CaCO}_{3}\right)$. In this case, the LM was collected in a rotary drum without passing through a washing step. This washing permits to remove more soluble chlorides content what would be good for cement materials production. The major variation in weight was seen in the TG/DTA in the range of $800-900^{\circ} \mathrm{C}$ around $40 \%$ (Figure 4 ). This variation represents the thermal decomposition of calcite $\left(\mathrm{CaCO}_{3}\right)$ and evidences the X-ray diffraction result.

\subsection{Cement lime mud formulations}

\subsubsection{Fresh state properties}

In general, LM-containing samples modified the rheological behaviour (37) in different levels as indicate in the Figure 5. Mortars containing 30\% LM showed highest torque and yield stress values along the time. The presence of fine particles in the mixtures requires an extra dosage of water
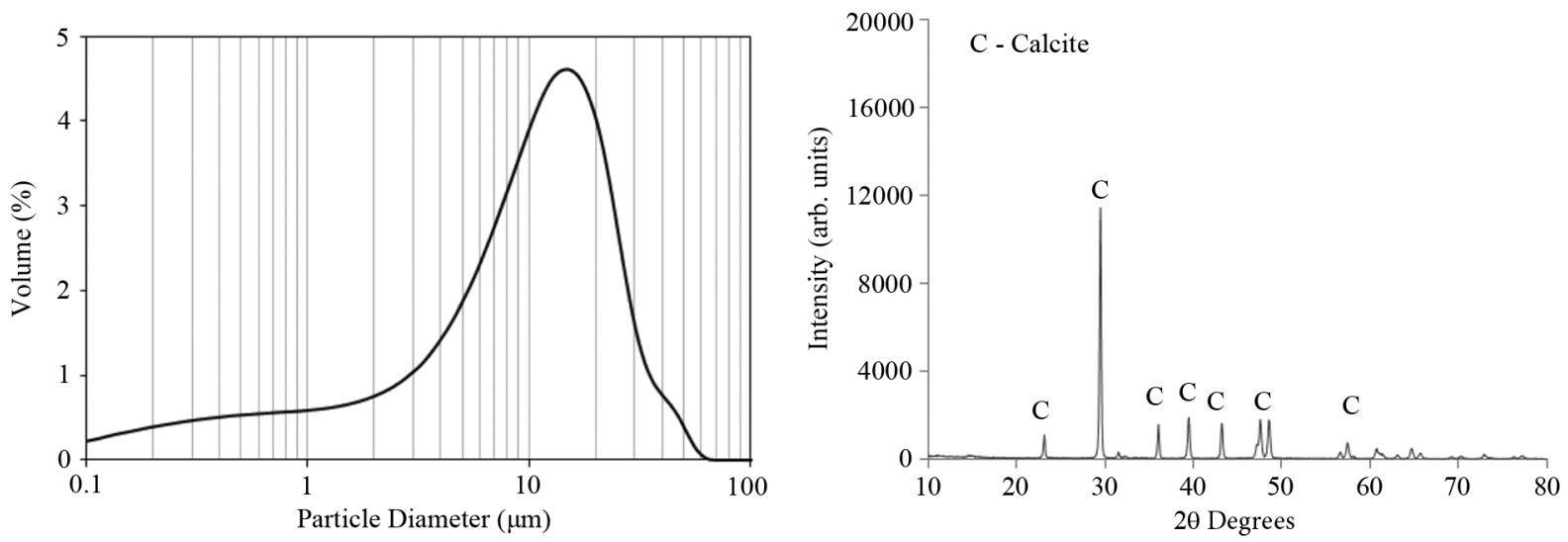

FIGURE 2. Particle size distribution and DRX results of lime mud $(\mathrm{C}=$ calcite $)$.

TABLE 2. Lime mud and CEM II 32.5 physical and chemical characteristics

\begin{tabular}{|c|c|c|c|c|c|c|c|c|c|c|c|c|c|c|}
\hline & ${ }^{1} \mathrm{RD}$ & ${ }^{2} \mathrm{SA}$ & MO & LOI & $\mathrm{SiO}_{2}$ & $\mathrm{Al}_{2} \mathrm{O}_{3}$ & $\mathrm{Fe}_{2} \mathrm{O}_{3}$ & MgO & $\mathrm{CaO}$ & $\mathrm{Na}_{2} \mathrm{O}$ & $\mathrm{K}_{2} \mathrm{O}$ & $\mathrm{P}_{2} \mathrm{O}_{5}$ & ${ }^{3} \mathrm{SO}_{4}^{-2}$ & ${ }^{4} \mathrm{Cl}^{-}$ \\
\hline Parameter & $\mathrm{g} / \mathrm{cm}^{3}$ & $\mathrm{~m}^{2} / \mathrm{g}$ & & & & & & $\% \mathrm{wt}$ & & & & & & \\
\hline LM & 2.83 & 5.17 & 34 & 43.7 & 0.29 & 0.2 & 0.03 & 0.48 & 51.8 & 1.9 & 0.1 & 0.9 & 0.05 & 0.08 \\
\hline${ }^{5} \mathrm{OPC}$ & 2.98 & 5.18 & $<1$ & 14.0 & 15.4 & 3.82 & 2.36 & 1.41 & 58.5 & ND & NQ & NQ & $<3.5$ & $<0.1$ \\
\hline
\end{tabular}

${ }^{1}$ Real density; ${ }^{2}$ Specific area; ${ }^{3}$ Sulphates - According to NP EN 196-21; ${ }^{4}$ Chlorides - According to NP EN 196-2; ${ }^{5}$ Portland cement type II 32.5; ND - Not detected; NQ - Not quantified. 

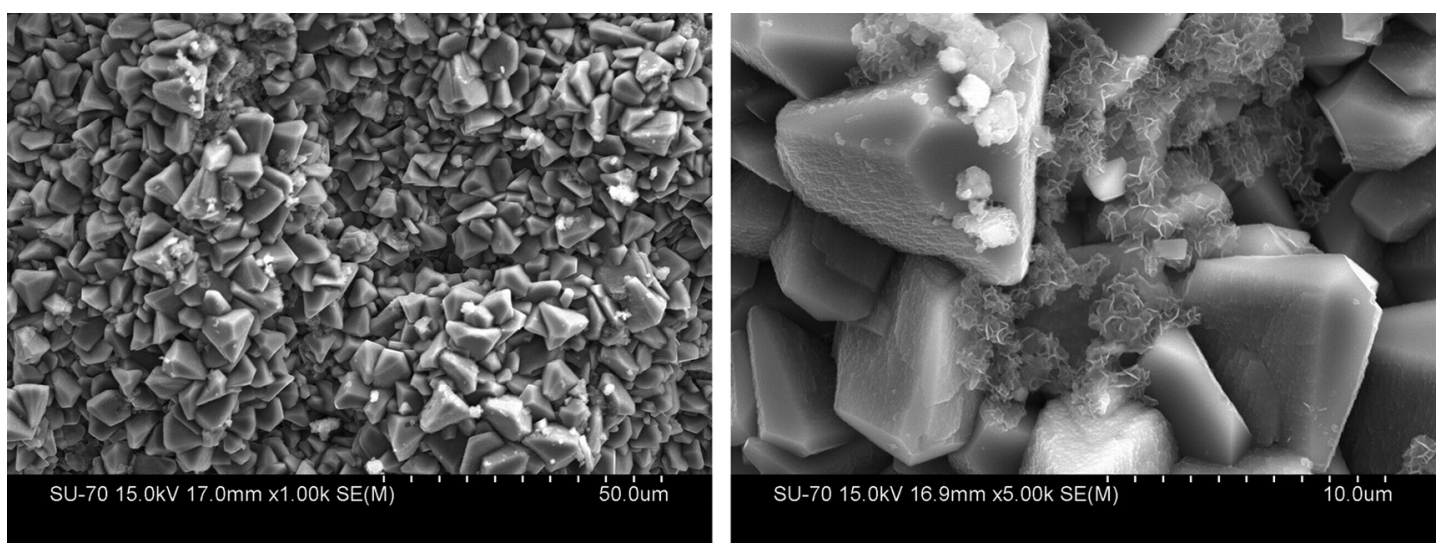

Figure 3. Microstructure of Lime mud.

or superplasticizer additive to keep the workability invariable. However, the mentioned factors influence significantly the rheological behaviour $(37,38)$ and the eventual impact due to fine particle is hard to be quantified. Is important remind here that the purpose of this experimental research is evaluate the real influence of LM, keeping them invariable. The reduction of plasticity can be related to the cohesiveness and intense particle attrition. Moreover, the presence of agglomeration or tridimensional structures formation can also affect particularly the torque and yield stress evolution along the test. In fact, the yield stress was the main rheological parameter affected regarding then plastic viscosity that remained almost constant at the end of the test.

As much as lime mud has been added the mortars spread (flow table) has decreased (Figure 6). The workability of mortars with $30 \%$ LM decreased $\sim 15 \%$ regarding the control sample. This fact can be due to the particle cohesion increasing and the remaining water content, as mentioned before.

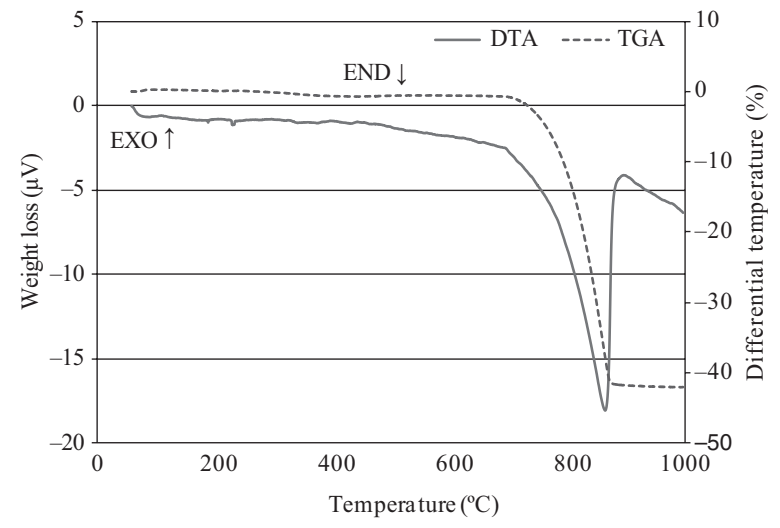

FIGURE 4. TGA/DTA curves of Lime mud.
The same behaviour was observed by Felekoglu et al. (2007) (24). The authors testing two types of materials (quarry waste limestone power - QLP, and powder produced by direct grinding of Limestone - PLP) showed that PLP compositions flowability do not differ significantly when compared with reference sample. On the other hand, an accentuate flowability decreasing was observed on QLP compositions. They concluded that this fact was associated to the powders particles fineness and shape. Finer powder (PLP) improved the spread flow values compared to coarser powder (QLP). The authors recalled that at first sight, due to the increased surface area, it seems not logical to expect higher flow values from a mixture incorporating finer powders when other variables are kept constant (in particular water content). However, just beside particle size, particle surface characteristics and surface porosity can play significant roles in designating the fresh state behaviour of cement pastes.

The setting time revealed distinct behavior when LM was added in the mixtures (Figure 6). The control sample exhibited the highest period, while LM30\%-containing mortars reduced $\sim 25 \%$. This fact could be related to water remaining in the cement matrix because of the fineness effect of the added particles in the LM composition. In addition, the $\mathrm{pH}$ of hydration solution can also influence the hydration mechanism in cements (15). Some other factors can also contribute to the setting anticipation, i.e. the presence of $\mathrm{Cl}^{-}$ions on LM. Chlorides exert some influence on the kinetics of hydration, becoming higher in cement with extra dosage of LM. However, according to the EN 998-1:2003 standard, the global content of $\mathrm{Cl}^{-}$ions should not exceed $0.1 \mathrm{wt} . \%$ of mortar/ concrete constitution, since the efflorescence formation is often observed, compromising the durability of the material (38-40). Besides, the reaction between $\mathrm{Cl}^{-}$ions and $\mathrm{C}_{3} \mathrm{~A}$ (tricalcium aluminate) or $\mathrm{C} 4 \mathrm{AF}$ (tetracalcium aluminoferrite) imply in 

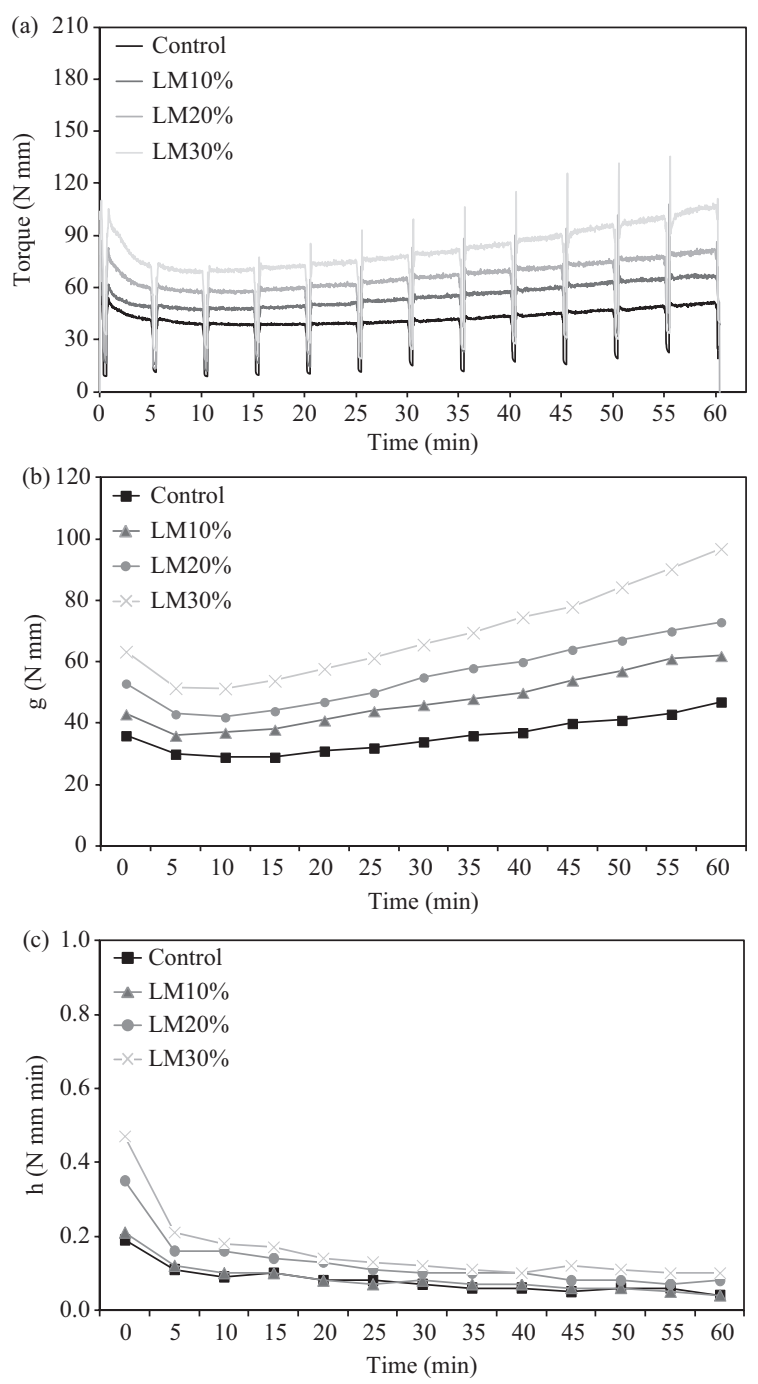

Figure 5. Torque (a), Yield stress (b), Plastic Viscosity (c) evolution during rheological testing of distinct mortars.

the chloroaluminates formation (40), in which the expansion occurrence increase the porosity that diminishes the mechanical strength.

The kinetics of hydration results measured by calorimetric are illustrated in the Figure 7. The maximum values of exothermic peak were registered after a period of $12 \mathrm{~h}$. In general, two main peaks can be observed, when the Portland cement is mixed with the water (41), as follows: (i) the first peak occurs few minutes after contact with water, where several $\mathrm{Ca}^{2+}, \mathrm{SO}_{4}^{2-}, \mathrm{Na}^{+}, \mathrm{K}^{+}$, and $\mathrm{OH}^{-}$ions are release to the aqueous solution from gypsum, $\mathrm{C}_{3} \mathrm{~S}, \mathrm{C}_{3} \mathrm{~A}$ and $\mathrm{C}_{4} \mathrm{AF}$ phases; (ii) the second peaks occur is caused by faster crystallization of $\mathrm{CH}$ and C-S-H. In both of cases, the presence of LM did not influence significant the results regarding the control sample. In fact, developed studies demonstrated that cements with small additions of limestone filler could be expected to

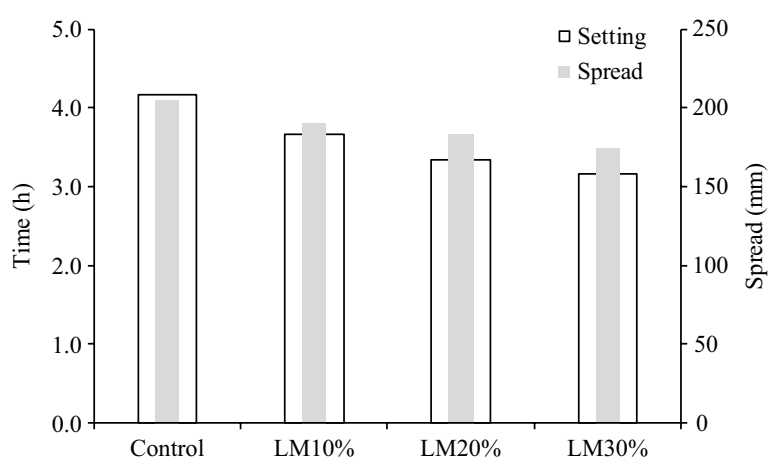

FIGURE 6. Setting and spread diameter of cement lime mud mortars.

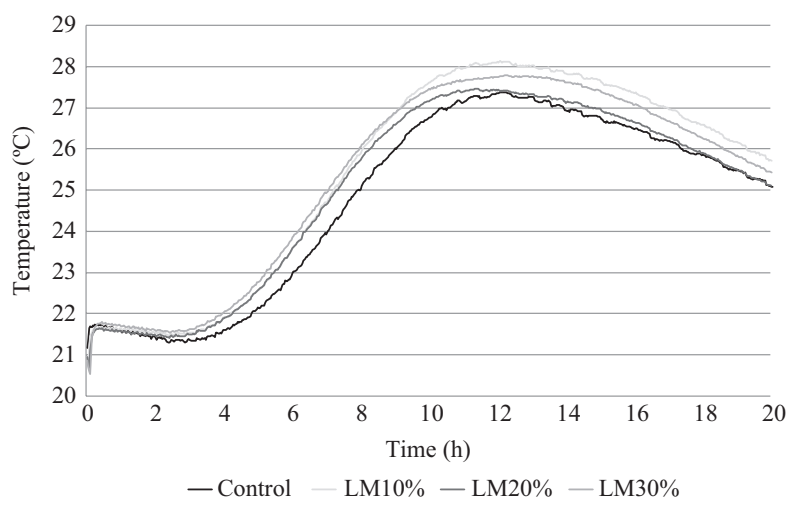

Figure 7. Calorimetric evaluation of hydration process of cement lime mud pastes.

have better performance if they have higher $\mathrm{C}_{3} \mathrm{~S}$ content and at the beginning of hydration, limestone do not significantly change the heat of hydration (22). Vuk et al. (2001) (22) also verified that the addition of limestone exhibited a strong effect on the initial setting measured by Vicat needle. The authors suggested that setting time is related to the type of used clinker and fineness cement (higher the limestone addition higher was the fineness of cement).

\subsubsection{Hardened state properties}

The mechanical and physical properties of the freshly prepared and hardened mortars containing LM are listed in Table 3. Some authors consider the effect of limestone on cement to be only physical, taking into account the increase in strength (42).

In this case, the mechanical strength of mortars (7, 28 and 90 days) did not show any significant differences between the studied compositions and the control mortar (Table 3). The compressive strength of LM containing samples increased around 8\% compared to the control sample at 28 days of curing. This difference between samples decreased at 90 days, but not significantly. 
TABLE 3. Lime mud and control mortars properties (SD - Standard Deviation)

\begin{tabular}{lcccc}
\hline Samples & Control & LM10 $\%$ & LM20 $\%$ & LM30 $\%$ \\
\hline Apparent Density & 2.14 & 2.13 & 2.12 & 2.12 \\
Rf $(\mathrm{MPa})[7 / 28 / 90$ days $]$ & $5.5 / 5.3 / 5.3$ & $5.2 / 5.1 / 5.6$ & $4.9 / 4.9 / 5.4$ & $5.1 / 4.2 / 5.6$ \\
$\mathrm{Rc}(\mathrm{MPa})[7 / 28 / 90$ days] & $17.1 / 17.9 / 22.3$ & $16.6 / 19.4 / 23.1$ & $16.0 / 19.4 / 22.2$ & $18.3 / 19.4 / 22.6$ \\
$\mathrm{~B}\left(\mathrm{~g} / \mathrm{cm}^{3}\right)[7 / 28 / 90$ days] & $1.86 / 19.2 / 1.93$ & $1.95 / 1.91 / 1.94$ & $1.93 / 1.90 / 1.93$ & $1.90 / 1.80 / 1.93$ \\
$\mathrm{WA}(\%)$ & $12.2 / 12.5 / 10.8$ & $12.1 / 12.412 .2$ & $12.0 / 12.2 / 10.7$ & $11.7 / 12.0 / 10.6$ \\
$\mathrm{C}\left(\mathrm{kg} / \mathrm{m}^{2}\right)[28$ days $]$ & 3.40 & 2.63 & 2.23 & 2.24 \\
Particle $<0.075 \mathrm{~mm}(\%)$ & 22.3 & 25.9 & 27.1 & 29.9 \\
\hline
\end{tabular}

Rf - Flexural strength; Rc - Compressive strength; B - Bulk density; WA - Water absorption; C - Coeficient of capillary.

According to the results obtained for all mechanical strengths, LM does not influence in a negative way the mortars properties which suggest that this waste could be used as alternative material for conventional fine aggregates replacement. Specifically in terms of bulk, the filler effect is obvious, whereby mortar densifies up to an optimum value situated between 10 and $20 \%$ of LM amount. Nevertheless, it is observed that mixes with $30 \%$ of LM presented a slightly decreasing on this parameter at 28 days of curing. This fact was also observed by Bénérina et al. (2005) (43). They proved that a density increase of dry mix up to an optical value of filler amount which represents 9 to 16\% sand mass replacement (depending on the sand), and a regular decrease for higher proportions. They interpreted this as filler powder first filling voids around sand grains, up to the optimum and concluded that higher filler amounts, those voids being completely filled; filler powder occupies the place of sand grains, hence diminishing sand proportion, and consequently the mix density.

The mortars capillarity was measured for a period of about 90 minutes (Table 3). The mortars absorption behaviour can be related to the pores content and/or pore sizes present in the mortars surface contact area. As much as the LM content increases in the cement mortars, lower becomes the capillarity coefficient. Many factors could influence this parameter and also it might be associated with the mortars structural arrangement. As the LM particles sizes are finer than the used sand, they could fill out same spaces inside the cement matrix causing this capillarity decreasing effect. The improvement is ascribed to reduced porosity (44). Regarding the filler effect phenomena, Moosberg-Bustnes et al. (2004) (45) observed that up to certain amount, the insertion of fine filler particles allows denser packing of cement paste and Benachour et al. (2008) (23) demonstrated that higher filler content increases the total porosity, but the macro-porous population diminishes in relation to the micro-porous.

\section{CONCLUSIONS}

This paper showed that samples prepared with higher dosages of $\mathrm{CaCO}_{3}$ present in the LM makes this waste an interesting material to be used as a fine mineral aggregate in cement-based-mortars.

If flow table and rheometer are used to define mortars formulations the maximum amount to be added is restricted. In fact, the rheometer limited the LM content to $30 \%$ maximum. The yield stress increased with the content of LM and along the test time. The plastic viscosity did not showed noticeable change after the first 10 min of test, being the yield stress the rheological parameter that suffers the highest influence of LC incorporation. The spread on table of mortars containing 30\% LM decreased about $15 \%$ regarding the REF. The mechanical strength was not significantly influenced by LM addition.

Regarding the economic aspects, there would be an opportunity to avoid the landfill of thousand tonnes of LM per year due to the expressive waste volume generated and, at the same time, savings in a natural raw material such as limestone could be achieved. Nevertheless, the moisture content of the LM has to be eliminated in case of using this waste as filler in dry-mixed industrial mortar preparation.

\section{ACKNOWLEDGEMENTS}

The authors would like to thank RAIZ and Portucel Soporcel group for their valuable help and contribution in this work. The authors also acknowledge FCT - Fundação para a Ciência e Tecnologia (grant SRFH/BD/75182/2010) for financial support for this work.

\section{REFERENCES}

1. Binici, H.; Shah, T.; Aksogan, O.; Kaplan, H. (2008) Durability of concrete made with granite and marble as recycle aggregates. J. Mat. Proc. Tech. 208, 299-308. http:// dx.doi.org/10.1016/j.jmatprotec.2007.12.120. 
2. UMTC (1995) Use of recycled materials and recycled products in highway construction. University of Massachusetts Transportation Center Report UMTC-95-1, US, pp. 238-245.

3. OECD (1997). Road Transport Research: Recycling Strategies for Road Works. Organization for Economic Co-operation and Development (OECD), Paris, France, pp. $140-148$.

4. Monte, M.C.; Fuente, E.; Blanco, A.; Negro, C. (2009) Waste management from pulp and paper production in the European Union. Was. Manag. Res. 29, 293-308. http:// dx.doi.org/10.1016/j.wasman.2008.02.002.

5. Modolo, R.; Benta, A.; Ferreira, V.M.; Machado, L.M. (2010) Pulp and paper plant wastes valorisation in bituminous mixes. Was. Manag. 30, 685-696. http://dx.doi. org/10.1016/j.wasman.2009.11.005.

6. Ahmadi, B.; Al-Khaja, W. (2001) Utilization of paper waste sludge in the building construction industry. Resour. Conser. Rec. 32 [2], 105-113. http://dx.doi.org/10.1016/ S0921-3449(01)00051-9.

7. Coutinho, J.S.; Garcia, M.L. (2008) Investigação inicial de resíduos da indústria de pasta de papel. In: Inovação na Construção Sustentável, v.1, 173-184, ISBN: 978989-95978-0-8.

8. Cernec, F.; Zule, J.; Moze, A.; Ivanu, A. (2005) Chemical and microbiological stability of waste sludge from paper industry intended for brick production. Was. Manag. Res. 23, 106-112. http://dx.doi.org/10.1177/0734242X05053662.

9. Modolo, R.; Ferreira, V.M.; Machado, L.M.; Rodrigues, M.; Coelho, I. (2011) Construction materials as a waste management solution for cellulose sludge. Was. Manag. 31, 370-377. http://dx.doi.org/10.1016/j.wasman.2010.09.017.

10. Decree n. ${ }^{\circ} 209$ (2004) Portuguese legislation about the European list of wastes in accordance with Commission Decision 2000/532/EC of 3 May 2000 replacing Decision 94/3/EC establishing a list of wastes pursuant to Article 1(a) of Council Directive 75/442/EEC on waste and Council Decision 94/904/EC establishing a list of hazardous waste pursuant to Article 1(4) of Council Directive 91/689/EEC on hazardous waste.

11. Gaskin, J. (2004) Land application of pulp mill lime mud. University of Georgia, College of Agriculture and Environmental Sciences, Cooperative Extension Service along with the Pollution Prevention Assistance Division. Bulletin 1249, Georgia, USA.

12. Li, Y.J.; Sun, R.Y.; Liu, C.T.; et al. (2012) $\mathrm{CO}_{2}$ capture by carbide slag from chlor-alkali plant in calcination/ carbonation cycles. Int J Greenhouse Gas Control 9, 117123. http://dx.doi.org/10.1016/j.ijggc.2012.03.012.

13. Ampadu, O.K.; Torii, K. (2002) Chloride ingress and steel corrosion in cement mortars incorporation low-quality fly ashes. Cem. Concr. Res. 32, 893-901. http://dx.doi.org/ 10.1016/S0008-8846(02)00721-4.

14. Cordeiro, G.C.; Toledo Filho, R.D.; Tavares, L.M.; Fairbairn E.M.R. (2008) Pozzolanic activity and filler effect of sugar cane bagasse ash in Portland cement and lime mortars. Cem. Concr. Comp. 30 [5], 410-418. http:// dx.doi.org/10.1016/j.cemconcomp.2008.01.001.

15. Rajamma, R.; Tarelho, L.A.C.; Alen, G.C.; Labrincha, J.A.; Ferreira, V.M. (2009) Characterisation and use of biomass fly ash in cement-based materials. J. Hazard. Mat. 172, 10491060. http://dx.doi.org/10.1016/j.jhazmat.2009.07.109.

16. Taylor, P.C.; Tait, R.B. (1999) Effects of fly, ash on fatigue and fracture properties of hardened cement mortars. Cem. Concr. Comp. 21 [3], 223-232. http://dx.doi.org/10.1016/ S0958-9465(99)00005-0.

17. Modolo, R.C.E.; Ferreira, V.M.; Tarelho, L.A.; Labrincha, J.A.; Senff, L.; Silva, L. (2013) Mortar formulations with bottom ash from biomass combustion. Constr. Build. Mat. 45, 275-281. http://dx.doi.org/10.1016/j.conbuildmat. 2013.03.093.

18. Pérez-Carrión, M.; Baeza-Brotons, F.; Payá J. Saval, J.M. Zornoza, E.; Borrachero, M.; Garcés, P. (2014) Potential use of sewage sludge ash (SSA) as a cement replacement in precast concrete blocks Mater. Construcc. 64 [313], e002. http://dx.doi.org/10.3989/mc.2014.06312.
19. Argiz, C.; Menéndez, E.; Sanjuán, M.A. (2013) Effect of mixes made of coal bottom ash and fly ash on the mechanical strength and porosity of Portland cement. Mater. Construcc. 63 [309], 49-64. http://dx.doi.org/10.3989/ mc.2013.03911.

20. Eroğlu, H.; Acar Uçüncü, H.H.; İmamoğlu, O. (2006) Soil stabilization of roads sub-base using lime-mud waste from the chemical recovery process in alkaline pulp mill. Jour. Appl. Sci. 6 [5] 1199-1203; ISSN 1812-5654.

21. Eroğlu, H.; Acar Uçüncü, H.H.; İmamoğlu, O. (2007) The effect of dry sludge addition supplied from pulp mill on the compressive strength of cement. Journal of the University of Chemical Technology and Metallurgy 42 [2]. 169-174.

22. Vuk, T.; Tinta, V.; Gabrovšek, R.; Kaučič, V. (2001) The effects of limestone addition, clinker type and fineness on properties of Portland cement. Cem. Concr. Res. 31, 135139. http://dx.doi.org/10.1016/S0008-8846(00)00427-0

23. Benachour, Y.; Davy, C.A.; Skoczylas, F.; Houari, H. (2008) Effect of a high calcite filler addition upon microstructural, mechanical, shrinkage and transport properties of a mortar. Cem. Concr Res. 38, 727-36. http://dx.doi. org/10.1016/j.cemconres.2008.02.007.

24. Felekoglu, B. (2007) Utilisation of high volumes of limestone quarry wastes in concrete industry (self-compacting concrete case). Resour. Conser Rec., 51 [4], 770-791. http:// dx.doi.org/10.1016/j.resconrec.2006.12.004

25. EN 13139: 2003. Aggregates for Mortars.

26. ISO/TS 17892-3: 2004. Geotechnical investigation and testing laboratory testing of soil. Determination of particle density - Pycnometer method.

27. Paiva, H.; Esteves, L.P.; Cachim, P.B.; Ferreira, V.M. (2009) Rheology and hardened properties of single-coat render mortars with different. Constr. Build. Mat. 23 [2], 11411146. http://dx.doi.org/10.1016/j.conbuildmat.2008.06.001.

28. Ferraris, C.F.; Brower, L.; Ozyıldırım, C.; Daczko, J. (2000) Workability of self-compacting concrete. In: Intern. Symp. High Perform. Concr. Proceedings. Florida: National Institute of Standards and Technology, 398-407.

29. Banfill, P.F.G. (2003) The rheology of fresh cement and concrete - a review, Proc. of 11th Intern. Congr. Chem. Cem., 50-62.

30. Senff, L.; Tobaldi, D.M.; Lucas, S.; Hotza, D.; Ferreira, V.M.; Labrincha, J.A. (2012) Formulation of mortars with nano- $\mathrm{SiO}_{2}$ and nano- $\mathrm{TiO}_{2}$ for degradation of pollutants in buildings. Comp. Part B, Eng. 44 [1], 40-47. http://dx.doi. org/10.1016/j.compositesb.2012.07.022.

31. EN 1015-3:2007. Methods of test for mortar for masonry: determination of consistence of fresh mortar (by flow table).

32. NP EN 196-3: 2005. Methods of testing cement. Determination of setting times and soundness.

33. EN 1015-11: 1999. Methods of test for mortar for masonry - Part 11: Determination of flexural and compressive strength of hardened mortar.

34. EN 1015-2: 1998. Methods of test for mortar for masonry Part 2: Bulk sampling of mortars and preparation of test mortars.

35. EN 1015-10: 1999. Methods of test for mortar for masonry - Part 10: Determination of dry bulk density of hardened mortar.

36. EN 1015-18: 2002. Methods of test for mortar for masonry. Water absorption by capillary.

37. Senff, L.; Hotza, D.; Labrincha, J.L. (2011) Effect of lightweight aggregates addition on the rheological properties and the hardened state of mortars. Appl. Rheol. 21 [1], 13668 (8 pages). http://dx.doi.org/10.3933/ApplRheol-2113668.

38. Vaysburd, A.M.; Emmons, P.H. (2004) Corrosion inhibitors and other protective systems in concrete repair: concepts or misconcepts. Cem. Concr. Comp. 26 [3], 255-263. http://dx.doi.org/10.1016/S0958-9465(03)00044-1.

39. Kaushik, S.K.; Islam, S. (1995) Suitability of sea water for mixing structural concrete exposed to a marine environment. Cem. Concr. Comp. 17 [3], 177-185. http://dx.doi. org/10.1016/0958-9465(95)00015-5. 
40. Sanjuan, M.A. (1997) Formation of chloroaluminates in calcium aluminate cements cured at high temperatures and exposed to chloride solutions. J. Mat. Sci. 32 [23], 6207-13.

41. Older, I. (1998) Lea's chemistry of cement and concrete. Arnold, London, (1998).

42. Soroka, I.; Stern, N. (1976) Calcareous fillers and the compressive strength of portland cement. Cem. Concr. Res. 6 [3], 367-376. http://dx.doi.org/10.1016/0008-8846(76) 90099-5.
43. Soroka, I.; Setter, N. (1977) The effect of fillers on strength of cement mortars. Cem. Concr. Res. 7 [4], 449-456. http:// dx.doi.org/10.1016/0008-8846(77)90073-4.

44. Bédérina, M.; Khenfer, M.M.; Dheilly, R.M.; Quéneudec, M. (2005) Reuse of local sand: effect of limestone filler proportion on the rheological and mechanical properties of different sand concretes. Cem. Concr. Res. 35 [6],11721179. http://dx.doi.org/10.1016/j.cemconres.2004.07.006.

45. Moosberg-Bustnes, H.; Lagerblad, B.; Forssberg, E. (2004) The function of filers in concrete. Mater. Struct. 37, 74-81. 